\title{
Accounting of Overhead Costs at the Agricultural Enterprise Applying ABC Method
}

\author{
Zdorovets Y.I.* \\ Chair of Economic Theory and Agro-industrial Complex \\ Economics \\ Belgorod State Agricultural University named after V. Gorin \\ Belgorod, Russia \\ e-mail: zdorovec1980@mail.ru
}

\section{Goncharenko O.V.}

Chair of Economic Theory and Agro-industrial Complex Economics

Belgorod State Agricultural University named after V. Gorin Belgorod, Russia

e-mail: olga.goncharenko.25@yandex.ru

\author{
Nasedkina T.I \\ Chair of Accounting, Analysis and Finance \\ Belgorod State Agricultural University named after V. Gorin \\ Belgorod, Russia \\ e-mail: t.nasedkina2012@yandex.ru \\ Chernych A.I. \\ Chair of Accounting, Analysis and Finance \\ Belgorod State Agricultural University named after V. Gorin \\ Belgorod, Russia \\ e-mail: a9040878030@yandex.ru
}

\begin{abstract}
The subject of the research is current approaches to expenditure records of organizing and managing of an agricultural enterprise production. The goal of research is to improve the overhead costs allocation of an agricultural enterprise taking into account an integrated approach to enterprise cost management. The article describes the main approaches to the costs information generation of organizing and managing production taking into account the specifics of agricultural enterprise activities. In the research the features of accounting and allocation of the enterprise $s$ overhead costs, the main stages of $\mathrm{ABC}$ method applying in overhead costs allocation and cost accounting of crop production were determined. The results presented in the research allowed concluding that it is necessary to apply integrated approach to the process of information generating on the costs of production organizing and managing as a result of their impact on the production cost of agricultural products. The research presents the procedure for overhead costs allocation taking into account the proposed $\mathrm{ABC}$ method, gives a comparative description of the obtained results and the enterprise actual data, defines methodological approaches to information detailing in the framework of management accounting of an agricultural enterprise.
\end{abstract}

Keywords - production costs, crop production, cost-driver, overhead costs, general business expenses, $A B C$ method.

\section{INTRODUCTION}

Every commercial enterprise regardless of area of activities is aimed at gaining the maximum amount of profit. One of the components of the enterprise costs that affect the amount of the financial result is the cost of production organization and management. The cost management process in this case is aimed not to costs minimization, but to the efficient application of resources, partial costs savings as well as to increase added value formation at each stage of the production.

In agricultural enterprises of various specializations the basis of each type of cost management is the information generated in the accounting system and used in the future to analyze and make optimal management decisions. Accounting and control over the dynamics of costs for the production organization and management is one of the functions of the accounting service staff. If there is any mistake in the process of this information generation then it leads to wrong analysis and, consequently, wrong decisions in terms of cost management in general. On that basis it is necessary for accounting and overhead costs allocation to use new options, which are the most optimal for the enterprise. As for such costs analysis - for the most part comes to tracking the costs structure and dynamics, which is aimed at finding reserves to costs reduce. In this case, cost reduction should be carried out by those people, who are responsible for them and in those organization units where these costs arise.

\section{LITERATURE REVIEW}

The costs of production organization and management are an indispensable component of production costs. Their share in production, work and services costs depends on many factors: specialization in production, enterprise size, staff qualification, applied technological process and technological discipline, organization forms of labor and production, etc.

Russian and foreign economists' researches demonstrate that overhead costs have recently been growing in dynamics and occupy an increasing share in the structure of production (works, services) costs. It is due to the introduction of new technologies that require constant monitoring, increasing the number of managerial personnel, decreasing of control over various enterprise resources application and higher requirements for the organization of enterprise management process. In view of this one can note an increasing necessity to apply new approaches to the organization of administration process, to use new management methodological principles, to increase control over the expenditure of funds for the management apparatus maintenance, to analyze possible optimization options $[3,18,19]$. 
According to Urlikova N.V. opinion application of traditional approaches to costs accounting, allocation and analysis for production organization and management jeopardises the relevant information generation, which is used for enterprise strategic planning. At the same time, it is important to apply a process-oriented approach to accounting and cost allocation, which will help to generate more accurate information about enterprise costs [16].

The composition of overhead costs according to M.I. Fedorov is complex and one of their parts is connected with the technological process management in a particular industry and the other one is connected with the enterprise management as a whole [3]. So, the first part may include, for example, staff costs for key specialists of the industries: chief agronomist, key livestock specialist, head veterinarian, etc. These costs are included in production costs. The second component of costs includes administrative expenses as a whole for directors, financial and accounting services, etc $[8,9]$.

Kalmykova R.G. notes that managerial decision-making process with tactical and strategic nature is based on information on costs and financial results of the company. Today, the necessity for management accounting in the management system is not in question. But with the development of production systems and technologies, improvement of the management theory and practice it is important to improve and increase the quality of existing management accounting systems including in terms of overhead costs accounting [4].

It is necessary to take into account that the current regulatory acts regarding accounting have several options for overhead costs allocation: in proportion to the total costs amount (minus the cost of seeds, feed, semi-finished products), direct costs amount, amount of expenses for materials and wages, etc. In addition costs can be monthly attributed in the planned amount to accounting objects adjusted at the end of the year [15].

Meanwhile, in all manufacturing sectors it is clearly observed a tendency to increase the share of overhead costs in production cost. The most common (and fundamentally wrong) approach today is approach where all overhead costs are allocated to any one cost object (distribution base) hours of work or wages of the main production workers, working hours of equipment, the amount of material or direct costs, etc. $[11,13]$.

As for the overhead costs of crop farming sector E.B. Kurtsev supposes that brigade costs are allocated first. To do this the total costs amount recorded in unit's current account is divided by the total brigade cost minus seeds cost and thus one can obtain a distribution coefficient [7].

Zakharova O.V. believes that the analytical accounting of general business expenses is organized at the places of their occurrence, i.e. for each integrated team, department, as well as at the level of the entire commercial farm unit. The objects of allocation of general business expenses are analytical accounts of crop production, animal husbandry and industrial production. A special object is the costs of works and services providing to outside parties and services of own auxiliary productions [28]. At the same time, Kurtsev E.B. reminds that general business expenses may be charged to construction carried out in an economic way or in general to the enterprise financial result [17].

In addition it is necessary to take into account that first of all general business expenses of departments and integrated teams are allocated and carried to the production cost. At the second stage general business expenses related to the entire enterprise are allocated while the overhead costs don't include general production costs and general business expenses of departments and integrated teams. [1;2]

Panchenko S.A. thinks that traditionally costs allocation from accounts 25 and 26 to account 20 is made by the final month postings. Basically organization may use a method for so-called "premature" allocation for both accounting and tax purposes and record this method in orders on accounting policies for accounting and tax purposes. It may also provide the unnecessary of such allocation [12].

The important role in overhead costs allocation according to Romanov N.A. belongs to verifiable information on production cost, because in most cases information about the total amount of production costs is used in costs allocation for the production organization and management. Timeliness of choosing the most appropriate allocation base in the reporting period reduces the allocation conditionality of indirect costs and increases the calculating accuracy of production costs in general [14].

Melnikova E.A. believes that the management accounting system at the enterprise is the main tool for planning activities and implementing operational control over the efficient use of the organization's resources. It helps company managers identify the optimal proportions between fixed and variable costs, price and volume of sales, minimize entrepreneurial risk [10].

Karacharov D.S. and Chugai D.Y. show that it is important for the producer to determine the total self-cost of product unit when using most pricing methods. If the method of "self-cost plus profit margin" is used then the methods for allocating of general production costs and general business expenses play a key role in pricing. In practice, the following often happens: the planned price is determined by the "self-cost plus profit margin" method (information about costs is taken from planned estimates), then it is compared with the market price and one performs sale price adjustment of the product taking into account the enterprise position on the market. Therefore, the methodology of accounting and allocation of indirect costs is of interest both for monopolistic enterprises and for small enterprises [5].

At the same time, national theory and practice smoothly solves the issues of cost analysis of all output (sold) products, which allows identifying and using the reserves for its reduction. Naturally, low profitability or unprofitableness of any product may lead to a decision to exclude it from the production program. Moreover, it is often missed the fact that this situation may arise as a result of the incorrect allocation of indirect (overhead) costs between different types of products. 
O. A. Kharitonov notes that it is useful to remember when using the data on account 25 and 26 to calculate production cost using direct-costing method - one can obtain not quite real results. To calculate more accurate indicators of production cost using this method it is necessary to select real variable indirect costs from the general production costs and attach them to direct variable costs to determine the total variable costs. In addition, in many Western countries the direct-costing method is not recommended for the preparation of financial statements and for tax purposes. It is used specifically in management accounting for monitoring, economic analysis and management decisions [6]

We believe that, in principle, it is impossible to find any universal indicator, which could be the only one cost object for all overhead costs, i.e. that factor or indicator, the change of which affects the change in overhead costs value. The choice of one cost object for all overhead costs leads to a significant cost distortion of certain types of products. At the same time, the amount of overhead costs, which are accounted for certain products and, thus, their cost price is changed in some cases significantly, depending on the used cost object. Finally, any product that is cost-effective when using any one cost object may be unprofitable with a different way of overhead costs allocation, the level of business activity costs.

\section{MATERIALS AND METHODS}

To ensure the effective development of production and the optimal level of profitability, agricultural enterprises must conduct a continuous analysis not only of the situation on the market, but also monitor costs dynamics and their structure. Recently, in production costs structure a significant share is occupied by general production and general business expenses, which affects the total cost. At the same time, it is advisable to pay attention to various approaches to costs allocation to control this kind of costs. Properly organized accounting and allocation of this kind of costs can optimize the cost management process of the agricultural enterprise in a whole.

The object of the research was an agricultural enterprise, which produces pig products as the main component and raises crops for its own feed mill. The subject of the research was the current practice of cost accounting for production organization and management.

In the course of the research monographic, abstract-logical, economic-statistical, accounting and other research methods were used. As information sources we used data from the analytical accounting of costs for various kinds of agricultural production (crop products), which are used both at the enterprise and to outside parties.

The obtained results can be used by agricultural enterprises in practice of managerial accounting of production costs in order to increase the efficiency of managing production costs and, as a result, increase performance efficiency.

\section{RESULTS}

Considering the possibility of applying one or another approach to costs allocation for organization and production management it is wise to use actual information of the agricultural enterprise. In our case the research object was the agricultural production cooperative "Kolkhoz named after Gorin", which is a large agricultural enterprise of the Belgorod region that specializes in pig production. However, in order to ensure the development of the pig breeding industry, the enterprise raises crop production, which is used as part of enterprise`s industrial production for feed stuff production.

The accounting policy of the agricultural production cooperative "Kolkhoz named after Gorin" has established that overhead costs are the costs of organizing and main industries management and include various production costs that can not be directly attributed to one or another nomenclature group, as well as costs for general production management. General business expenses include costs connected with production management for the enterprise in a whole and sites as a property and financial complex.

General production costs are divided by industry criteria: crop production, animal husbandry and industrial production. It should be noted that despite the fact that the main production in the commercial farm unit has three directions (crop production, animal husbandry and feed stuff production) general production costs before transition to automated accounting in 2019 were divided by industry criteria only in two directions: crop production and animal husbandry.

For more accurate and reasonable costs allocation to their role it is extremely important to subdivide overhead costs depending on the place where they arise. This procedure enables the overhead costs of each organization unit to attribute to the costs of only this organization unit, which provides a more accurate calculation of production cost and most importantly it meets the accounting requirements for organization unit. So, the accounting of overhead costs in the agricultural production cooperative "Kolkhoz named after Gorin" is maintained in the following units:

- general production of plant growing by sites

- general production of animal husbandry by farms,

- general guidance for types of activity (general production of plant growing, general production of animal husbandry, general production of animal husbandry in pig farming, general production of livestock farming, cattle, etc.).

All business life carried out by the organization is documented with supporting documents. These documents are primary accounting documents, on which basis accounting is conducted. The document that issue current fact of economic life has a dual purpose: firstly, this document is validate voucher, i.e. confirms the fact that the organization has committed a fact; secondly, the document is a primary accounting document on the basis of which accounting records are made.

During the year general production costs are allocated monthly to the main industries production cost in the amount of $15 \%$ of the actual basic wages of workers in livestock industry and $30 \%$ in crop industry. At the end of the year at the units of main production it is allocated the deviation in 
respective unit at self-cost of only those products (works, services), which are produced in this unit according to the cost objects of the main production and it is proportional to the wages of the main production personnel among the departments of the main production. For the division "General management by types of activity" it is allocated according to the cost objects of the main production in proportion to the wages of the main production personnel of the corresponding type of activity. For example, general production costs of site No. 1 is allocated only to products produced by site No. 1 and general production costs of crop production as an industry are allocated across all production areas of crop production to all produced products.

Improving management practices demands new accounting requirements. Despite the fact that in recent years there have been many changes in terms of accounting accounts, the indicators of financial statements have changed, however, accounting still can not provide a timely reflection of all facts of economic life while reducing labor and cash costs for its maintenance. The actual state of cost accounting for the organization and production management of the agricultural production cooperative "Kolkhoz named after Gorin" allows concluding that it is necessary to improve this area of accounting from the standpoint of applying modern methodological approaches.

The problem of accounting and overhead costs allocation remains one of the most important tasks in the national theory and practice of management accounting. On the one hand, overall development of the economy is facilitated by this and results to demonopolization, free pricing system and competitiveness. In such circumstances it is vital for the company to understand the cost of its products in general and the "breakeven-even point" in particular. On the other hand, new technologies increasing the complexity of agricultural production management especially at enterprises such as the agricultural production cooperative "Kolkhoz named after Gorin" determine the growth trend in overhead costs. At the same time, the latest ones as it is shown by experience of reducing personnel and rental costs, which have appeared during the crisis years, is much more manageable in terms of profit reserves and growth in the company's profitability than direct costs. In addition from management accounting point of view the question is not even to allocate indirect costs in current way between the objects of costing and determine selfcost of particular types of agricultural products, but to find an allocation method, which would reflect the real relationship between the allocated costs and objects on which these costs are allocated. The main difficulty here is in the dissimilar nature of indirect costs. The application of a single allocation method to all indirect costs does not take into account their nature, causes of occurrence, heterogeneity and finally distorts the construction work costs and therefore it is unacceptable. The grouping of indirect costs by accounting objects taking into account the following allocation of each group on an individual basis increases calculations reliability and at the same time increasing the complexity of accounting work.

In practice the concept of accounting of overhead costs based on $\mathrm{ABC}$ method is the most progressive for today. Comparing it with the traditional cost assignment network it should be noted that in the functional system (ABC method) overhead costs are allocated by main activities and not by units.

The allocation algorithm of overhead costs on production costs according to ABC method consists of several stages:

1) establishment of basic processes associated with production;

2) assessment of costs for each identified process;

3) establishment of cost drivers for each identified process;

4) application of cost drivers rate to products (cost units).

Driver rate is calculated for all cost hold points by processes by the formula:

$$
\mathrm{RD}=\mathrm{P} / \mathrm{D},
$$

where $\mathrm{RD}$ - cost drive rate;

$\mathrm{P}$ - cost amount by process;

$\mathrm{D}$ - cost driver (number of operations)

For better visualize the results of functional method we present a calculation based on data from the agricultural production cooperative "Kolkhoz named after Gorin". As an example, we use the data on account 25 "General production costs" subaccount 1 "Crop production". The cost object value at the enterprise must be calculated by objects in the context of centers of costs arising. In relation to the agricultural production cooperative "Kolkhoz named after Gorin" it is necessary to carry out the calculation for four sites of crop production: site No. 1 "Bessonovka"; site No. 2 "Orlovka"; site No. 3 "Shchetinovka"; site No. 4 "Solokhi".

The objects of calculation are corn and winter wheat. Calculation of direct production costs for the reporting 2019 year is presented in table 01 .

TABLE I. CALCULATION OF DIRECT PRODUCTION COSTS *

\begin{tabular}{|c|c|c|c|c|c|}
\hline $\begin{array}{c}\text { Produ } \\
\text { ction } \\
\text { type }\end{array}$ & $\begin{array}{c}\text { Volume } \\
\text { of } \\
\text { produc } \\
\text { tion, } \\
\text { centner }\end{array}$ & $\begin{array}{c}\text { Direct } \\
\text { labor } \\
\text { costs with } \\
\text { deductio } \\
\text { ns, rub. }\end{array}$ & $\begin{array}{c}\text { Direct } \\
\text { material } \\
\text { costs per } \\
\text { unit, rub. }\end{array}$ & $\begin{array}{c}\text { Total } \\
\text { material } \\
\text { costs, rub. }\end{array}$ & $\begin{array}{c}\text { Other } \\
\text { production } \\
\text { costs, } \\
\text { thousand } \\
\text { rubles }\end{array}$ \\
\hline Corn & 318931 & 8759016 & 253,92 & 80984025 & 23127650 \\
\hline Cereal & 178781 & 6677125 & 179,24 & 32044158 & 12454789 \\
\hline Total & - & 15436141 & - & 113028183 & 35582439 \\
\hline
\end{tabular}

After direct costs determining it is necessary to fall on allocation distribution of overhead costs generated during the conduct of business processes. The list of processes that are not directly dependent on crop production volume includes: cost of delivering the harvested crop to the granary, transporting cost of main production workers, vehicles repairing, depreciation, safety ensuring of products and containers (table 02). This approach means that it is necessary to specify processes by all types of overhead costs. In the table we shall consider only an example of cost-drivers development for the part of overhead costs of crop production. 
TABLE II. TYPES OF ACTIVITIES AND FOLLOWING COST OBJECTS *

\begin{tabular}{|l|l|l|l|l|}
\hline \multirow{2}{*}{$\begin{array}{l}\text { Description of } \\
\text { costs by process }\end{array}$} & \multicolumn{1}{|c|}{ Cost driver } & $\begin{array}{c}\text { Costs by } \\
\text { process, } \\
\text { rub. }\end{array}$ & $\begin{array}{c}\text { The value of cost } \\
\text { object (number of } \\
\text { operations) by } \\
\text { type of crop }\end{array}$ \\
\cline { 4 - 5 } & & Corn & $\begin{array}{c}\text { Winter } \\
\text { wheat }\end{array}$ \\
\hline $\begin{array}{l}\text { Costs for labor } \\
\text { and occupational } \\
\text { safety }\end{array}$ & $\begin{array}{l}\text { Number of person- } \\
\text { hour of current } \\
\text { field visits to the } \\
\text { objects of safety } \\
\text { engineers, person / } \\
\text { hour }\end{array}$ & 1564282 & 321 & 214 \\
\hline $\begin{array}{l}\text { Delivery of } \\
\text { specialists to the } \\
\text { place of work }\end{array}$ & $\begin{array}{l}\text { Number of } \\
\text { deliveries }\end{array}$ & 3886883 & 1430 & 955 \\
\hline $\begin{array}{l}\text { Machinery and } \\
\text { equipment } \\
\text { switch-over }\end{array}$ & $\begin{array}{l}\text { Number of } \\
\text { changeover }\end{array}$ & 5205010 & 2115 & 1412 \\
\hline $\begin{array}{l}\text { Depreciation of } \\
\text { vehicles }\end{array}$ & $\begin{array}{l}\text { Number of used } \\
\text { vehicles }\end{array}$ & 1623836 & 1682 & 1123 \\
\hline $\begin{array}{l}\text { Maintenance of } \\
\text { key specialists } \\
\text { activity of crop } \\
\text { production }\end{array}$ & $\begin{array}{l}\text { Staff number, } \\
\text { persons }\end{array}$ & 5423375 & 1485 & 992 \\
\hline $\begin{array}{l}\text { The costs for } \\
\text { fire-fighting and } \\
\text { watchmen } \\
\text { services }\end{array}$ & $\begin{array}{l}\text { Protected area, } \\
\text { sq.m }\end{array}$ & 5203330 & 4313 & 2880 \\
\hline
\end{tabular}

b. * calculated by the authors on the basis of data of the agricultural production cooperative "Kolkhoz named after Gorin"

For example, the process maintenance of activity of chief agronomist, heads of the plant growing sites and other persons belonging to industry specialists will group the costs on payroll accounting, social benefits and reserve for vacation payments at the enterprise. In this case, the cost-driver is the number of employees subordinate to the heads of departments. The costs of delivering employees to the sites is distributed in proportion to the number of deliveries, depreciation for such vehicles - the number of used vehicles, costs for occupational safety in the sites - the number of worked by safety engineers person-hour, etc.

In this example the data in table 02 allowed performing first two stages of applying the $\mathrm{ABC}$-costing method, i.e. identifying the processes associated with production and detect costs for each identified process. These calculations must be carried out monthly because it allows selected cost drivers.

The calculation of cost driver rates, carrying out in accordance with the above mentioned formula, is presented in table 03. In this case first of all one should to determine the total number of cost objects and then determine the cost-driver cost rate. For example by process "Costs for labor and occupational safety" the total number of operations was $592(294+298)$, the total cost was 1.730 .200 rubles, which means that the cost rate of cost-driver is 2922.63 rubles (1730200/592). These calculations are made for each process connected with the production of these types of products.

Driver rates allowed determining the cost of one production activity. Obtained rate values can be applied directly to calculation objects (table 04).
TABLE III. CALCULATION OF DRIVERS RATES BY PROCESSES

\begin{tabular}{|l|l|l|l|}
\hline \multicolumn{1}{|c|}{ Type of activity } & \multicolumn{1}{|c|}{$\begin{array}{c}\text { Costs P, } \\
\text { rub. }\end{array}$} & $\begin{array}{c}\text { Cost Objective } \\
\text { Value D } \\
\text { (number of } \\
\text { operation) }\end{array}$ & $\begin{array}{c}\text { Cost driver } \\
\text { rate } \mathbf{R}_{\mathbf{D}}\end{array}$ \\
\hline $\begin{array}{l}\text { Costs for labor and } \\
\text { occupational safety }\end{array}$ & 1564282 & 535 & 2922.63 \\
\hline $\begin{array}{l}\text { Delivery of specialists } \\
\text { to the place of work }\end{array}$ & 3886883 & 2385 & 1629.95 \\
\hline $\begin{array}{l}\text { Machinery and } \\
\text { equipment switch-over }\end{array}$ & 5205010 & 3527 & 1475.74 \\
\hline Depreciation of vehicles & 1623836 & 2805 & 578.93 \\
\hline $\begin{array}{l}\text { Maintenance of key } \\
\text { specialists activity of } \\
\text { crop production }\end{array}$ & 5423375 & 2477 & 1571.45 \\
\hline $\begin{array}{l}\text { The costs for fire- } \\
\text { fighting and watchmen } \\
\text { services }\end{array}$ & 5203330 & 7193 & 2189.78 \\
\hline
\end{tabular}

c. * calculated by the authors on the basis of data of the agricultural production cooperative "Kolkhoz named after Gorin"

TABLE IV. THE ALLOCATION OF OVERHEAD COSTS BY CROP PRODUCTION TYPES*

\begin{tabular}{|l|l|l|l|l|}
\hline \multicolumn{1}{|c|}{ Type of activity } & \multicolumn{2}{|c|}{ Corn } & \multicolumn{2}{c|}{ Winter wheat } \\
\cline { 2 - 5 } & $\begin{array}{c}\text { Number of } \\
\text { operation } \boldsymbol{D}\end{array}$ & $\begin{array}{c}\text { Cost, } \\
\text { rub. }\end{array}$ & $\begin{array}{c}\text { Number of } \\
\text { operation } \boldsymbol{D}\end{array}$ & $\begin{array}{c}\text { Cost, } \\
\text { rub. }\end{array}$ \\
\hline $\begin{array}{l}\text { Costs for labor and } \\
\text { occupational safety }\end{array}$ & 321 & 938003 & 214 & 626279 \\
\hline $\begin{array}{l}\text { Delivery of specialists to } \\
\text { the place of work }\end{array}$ & 1430 & 2330723 & 955 & 1556160 \\
\hline $\begin{array}{l}\text { Machinery and } \\
\text { equipment switch-over }\end{array}$ & 2115 & 3121122 & 1412 & 2083888 \\
\hline Depreciation of vehicles & 1682 & 973714 & 1123 & 650122 \\
\hline $\begin{array}{l}\text { Maintenance of key } \\
\text { specialists activity of } \\
\text { crop production }\end{array}$ & 1485 & 3252062 & 992 & 2171313 \\
\hline $\begin{array}{l}\text { The costs for fire- } \\
\text { fighting and watchmen } \\
\text { services }\end{array}$ & 4313 & 6777907 & 2880 & 4525423 \\
\hline
\end{tabular}

d. * calculated by the authors on the basis of data of the agricultural production cooperative "Kolkhoz named after Gorin"

The calculations demonstrate that the amount of overhead costs accrue to the production of 1 centner of corn is higher than the production of the same amount of winter wheat. The considered method of calculation allows analyzing costs of each crop clause-by-clause and identifying the cause of any deviations.

After processes of identifying and conducting preparatory calculations for each of them one can start to calculate production cost of particular types of crop production at the agricultural production cooperative "Kolkhoz named after Gorin" (table 05).

The re-allocation of overhead costs on the example of corn and winter wheat showed that under using the ABC method self-cost of corn is lower by 18.73 rubles and winter wheat on the contrary, is higher by 3.80 rubles.

Thus, the calculation by the ABC-costing method made it possible not only to determine the production cost of each type of product accurately, but also made it possible to estimate the amount of costs for each identified process. In this case, it makes a common sense to think about updating the equipment in order to avoid additional costs for its repair. For implementation the 
ABC model within the framework of the accounting system operating at agricultural enterprises it is proposed to activate additional subsystems of accounts.

TABLE V. PАСЧЕТ СЕБЕСТОИМОСТИ ПРОДУКЦИИ С УЧЕТОМ РАСПРЕДЕЛЕНИЯ ЗАТРАТ ПО МЕТОДУ АВС, РУБ.

\begin{tabular}{|c|c|c|}
\hline Account cost & Corn & Winter wheat \\
\hline \multicolumn{3}{|l|}{ Direct manufacturing costs } \\
\hline Material costs & 80984025 & 32044158 \\
\hline Labor costs & 6722192 & 5128360 \\
\hline Social benefits & 2036824 & 1548765 \\
\hline Other manufacturing costs & 23127650 & 12454789 \\
\hline Total direct manufacturing costs & 112870691 & 51176072 \\
\hline \multicolumn{3}{|l|}{ Overhead costs (general production costs) } \\
\hline Costs for labor and occupational safety & 938003 & 626279 \\
\hline Delivery of specialists to the place of work & 2330723 & 1556160 \\
\hline Machinery and equipment switch-over & 3121122 & 2083888 \\
\hline Depreciation of vehicles & 973714 & 650122 \\
\hline $\begin{array}{l}\text { Maintenance of key specialists activity of crop } \\
\text { production }\end{array}$ & 3252062 & 2171313 \\
\hline The costs for fire-fighting and watchmen services & 6777907 & 4525423 \\
\hline Other overhead costs & 6413658 & 4282223 \\
\hline Total overhead costs & 23807189 & 15895408 \\
\hline Total costs & 136677880 & 67071480 \\
\hline The number of produced products, centner & 318931 & 178781 \\
\hline Self-cost of 1 centner, rub. & 428.55 & 375.16 \\
\hline Self-cost of 1 centner before recalculation, rub. & 447.28 & 371.36 \\
\hline Deviation on 1 centner, rub. & -18.73 & +3.80 \\
\hline
\end{tabular}

e. * calculated by the authors on the basis of data of the agricultural production cooperative "Kolkhoz named after Gorin"

Controlling for current costs it is necessary to use the accounts of section III of the Chart of accounts of financial and economic activities of organizations "Production costs". Free account 30 can be used for costs accounting under ABC method while for each type of cost it is advisable to allocate own subaccount or to detail the analytical account because overhead costs composition at each enterprise depends on its specialization (table 06).

TABLE VI. SubaCCOUNTS TO ACCOUNT 30 "COSTS ON ABC"

\begin{tabular}{|l|l|}
\hline $\begin{array}{c}\text { № } \\
\text { subaccounts }\end{array}$ & \multicolumn{1}{c|}{ Name of subaccounts } \\
\hline 30.1 & Costs for labor and occupational safety \\
\hline 30.2 & Delivery of specialists to the place of work \\
\hline 30.3 & Machinery and equipment switch-over \\
\hline 30.4 & Depreciation of vehicles \\
\hline 30.5 & Maintenance of key specialists activity of crop production \\
\hline 30.6 & The costs for fire-fighting and watchmen services \\
\hline
\end{tabular}

f. * done by authors

Based on mentioned above we can make a conclusion that the use of free account subsystems within the framework of the $\mathrm{ABC}$ concept will provide more accurate data about expenditures, which will bring an opportunity for managers to take more informed decisions and achieve competitive advantage on agricultural market. As for general expenses of administration, in our opinion based on current accounting practice, it is wise to cover them funded with financial results. This approach allows covering administrative costs in the current reporting period and providing more objective assessment of the enterprise. In this case the following accounting record will be noted: D-t 90 "Sales" K-t 26 "General business expenses".

In general listed above proposals as well as competent accounting organization will provide an opportunity for the agricultural production cooperative "Kolkhoz named after Gorin" to reduce its costs and thereby increase the real profit, which can be obtained as a result of economic activity.

\section{V.CONCLUSION}

Any agricultural enterprise aimed at the achievement of the highest possible financial result when making optimal decisions pointed at the enterprise development, must take into account various components including costs. In this case it is necessary to take into account not only material and labor costs, but also pay attention to the costs of organizing and managing production, which occupy sufficient share in production costs structure for influence at the final result. Having examined the traditional approaches to organizing accounting of this type of costs and taking into account the specifics of agricultural activities we can note a necessity to use modern approaches in the practice of management accounting. In this case one can determine some directions:

- when organizing costs accounting for the organization and production management taking into account places where costs arise related to general production costs;

- use cost-drivers in costs allocation on organization and production management for more accurate costs allocation on production organization to a specific type of product;

- use adapting possibilities of chart of accounts in accounting in the frame of management accounting based on the specifics of information generation for enterprise`s costs management.

\section{References}

[1] E.A. Bazovkina, Z.A. Bozhchenko, "Analysis of enterprise`s financial result", Vector of econ., vol. 8, no. 38, p. 58, 2019

[2] Z.A. Bozhchenko, E.A. Golovaneva, "Peculiar features of calculation process in the terms of "direct costing" system application", Econ. and entrepreneurship, vol. 5, no. 106, pp. 982-984, 2019.

[3] M.I. Fedorov, "Influence of the methods of overhead costs allocation on management decisions making", Audit and taxation, vol. 9, pp. 6-9, 2017.

[4] R.G. Kalmykova, "Improving accounting and methods of allocation of general production costs and general expenses of administration". Retrieved from: http: // cyberleninka.ru.

[5] D.S. Karacharov, D.Y. Chugai, "Modern technologies for improving managerial communications in organization as a factor of its economic security", Communicol.: electr. Sci. J., vol. 3, pp. 22-28, 2018.

[6] O.A. Kharitonov, "Methodological approaches to the automation of management accounting systems in organizations", Account. and taxation, vol. 3, pp. 33-47, 2018.

[7] E.B. Kurtsev, "Accounting and allocation of overhead costs by units in a trade organization when adapting to IFRS", Manag. Account., vol. 3, pp. 22-28, 2018.

[8] I.N. Lozhnikov, "Accounting advice", Chief accountant. Appendix "Accounting in agriculture", 2018, vol. 4, pp. 6-9.

[9] Z.P. Medelyaev, E.B. Trunova, V.G. Shirobokov, "Improving management accounting as an element of the organization cost 
management system", Bull. of the Voronezh State Agricalt. Univer., vol. 12, no. 1(60), pp. 180-192, 2019.

[10] E.A. Melnikova, "Methods of allocation of overhead and general costs play a key role in pricing", Chief accountant, no. 2, pp. 4-8, 2019.

[11] T.I. Nasedkina, Features of overhead costs allocation in agricultural organizations, pp. 161-165, 2019 [Coll. Modern Economics: ensuring food security, Collection of sci. papers of the VI Int. Sci. and Pract. Conf.].

[12] S.A. Panchenko, "Methods of cost accounting for agricultural production in accordance with international financial reporting standards", Manag. Account., no. 5, pp. 11-15, 2018.

[13] L.A. Reshetnyak, L.I. Smurova, "Features of management accounting organizationin in pig industry", Bull. of the Belgorod Univer. of Cooperat., Econ. and Law, vol. 6, no. 73, pp. 256-264, 2018.

[14] N.A. Romanov, "Overhead costs: ways to reduce them", Financial and account. Consultat., no. 10, pp. 22-27, 2018.
[15] T.V. Savchenko, A.V. Ulez ko, L.V. Kiyashchenko, A.A. Tyutyunikov, Development of the family economies of the agricultural sector of Russia”, Int. Busin. Manag., vol. 6, pp. 1186-1189, 2015.

[16] N.V. Urlikova, "The optimal cost-allocation mechanism for effective cost control of produced products", Manag. Account., no. 10, pp. 44-51, 2017.

[17] O.V. Zakharova, "Analysis of typical mistakes in accounting and taxation", Financial newspaper, vol. 41, pp. 12-15, 2019.

[18] Y.I. Zdorovets, "Calculation features of production costs of grain crops", Bull. of the Belgorod Univer. of Cooperat., Econ. and Law, vol. 6, no. 73, pp. 275-282, 2018.

[19] O.I. Zolotareva, "To the question of research and improvement of organization of accounting and tax accounting in small and medium business", Innovat. in the agricult. sector: probl. and prosp., 4 , no. 24 pp. 122-130, 2019. 